ISSN 0853-8697

\title{
TEORI KUANTIFIKASI FUZI II SEBAGAI ALAT ANALISIS FAKTOR-FAKTOR KEPUASAN KONSUMEN TERHADAP SWALAYAN Kasus di Swalayan Indogrosir dan Alfa Yogyakarta
}

\author{
Budi Astuti, Sharly Putri \\ Jurusan Teknik Industri, Fakultas Teknologi Industri, \\ Universitas I slam Indonesia \\ Jl. Kaliurang Km. 14 Yogyakarta 55501
}

\begin{abstract}
Every company puts consumers' satisfaction as the main priority in service to win the competition among similar companies. The use of Fuzzy Quantification II for evaluating the costumers' satisfaction of two self-service supermarkets, namely Alfa and Indogrosir, had been done. A Ithough both Indogrosir and Alfa have the same characteristic as supermarkets, they differ in the company policies and each has their own superiorities. The satisfaction level which are formed by several qualitative data will be transformed into numerical one. These two supermarkets are treated as an External Standard V ariable ( y ) to become the objective function of purpose. There were 13 factors including the varieties and the quality of goods indicated as Parameter $V$ ariable which influence the satisfaction level. The results show that the varieties of goods are the most dominant factor for the costumers' satisfaction. Futhermore, it shows that the satisfaction level for Alfa Supermarket is 0.69 and for Indogrosir is 0.60 .
\end{abstract}

Keywords: consumers' satisfaction, fuzzy quantification, external standard variable.

\section{PENDAHULUAN}

Kepuasan konsumen sangat berperan penting untuk mempertahankan pangsa pasar yang saat ini cenderung semakin keras dan ketat persaingannya. $\mathrm{Hal}$ ini juga dialami oleh grosir dan retail yang bersifat Swalayan seperti Indogrosir dan Alfa. Keduanya memiliki karakteristik yang sama namun berbeda kebijakan strategi perusahaan dan memiliki keunggulan masing-masing. Konsumen saat ini juga semakin kritis dengan memiliki berbagai faktor keinginan yang beragam. Data kasar tentang tingkat kepuasan konsumen yang merupakan hasil evaluasi pendapat orang tidak secara normal diekspresikan secara numeris. Padahal ekspresi yang berbentuk kualitatif akan lebih mudah dibandingkan apabila secara numeris. Untuk itu Kuantifikasi Fuzy dapat digunakan untuk mengendalikan data-data kualitatif tingkat kepuasan tersebut dengan cara memetakan suatu ruang input kedalam ruang output. Sebagai contoh seberapa sejuk ruangan yang diinginkan, maka akan diatur putaran kipas angin yang ada pada ruangan tersebut. Atau seberapa cepat laju kendaraan yang diinginkan maka sopir akan mengatur pijakan gas kendaraannya. Pada masalah swalayan maka dapat diajukan penilaian derajat kepuasan sebagai berikut: sangat tidak senang, tidak senang, biasa, senang berbelanja dan sangat senang. Serta untuk kesesuaian atas 
kuisioner yang diajukan adalah sangat tidak sesuai, tidak sesuai, biasa, sesuai dan sangat sesuai. Seberapa sejuk, seberapa cepat laju kendaraan atau seberapa tingkat kepuasan konsumen pada kasus pelayanan di atas berkaitan dengan teknik kendali. Dengan logika fuzi diharapkan mampu untuk menganalisis kelakuan masyarakat, melakukan monitoring sehingga dengan metode ini akan dapat diketahui susunan atau tingkatan dari faktor-faktor yang menentukan tingkat kepuasan konsumen. Kuantifikasi Fuzi dikembangkan dengan Teori Kuantifikasi Fuzi II. Tujuan dari Teori Kuantifikasi Fuzi II adalah untuk mengekspresikan beberapa himpunan fuzi dalam variabel deskriptif kualitatif .Dengan metode ini diharapkan membantu ke dua Swalayan tersebut di atas untuk menetapkan urutan faktor kepuasan konsumen dan menetapkan kebijakan lebih lanjut agar dapat mengikat dan bahkan meningkatkan jumlah pelanggannya

\section{KUANTIFIKASI FUZI}

Untuk keperluan merepresentasikan pendapat orang secara numeris maka dibutuhkan metode kuantifikasi. Dalam penelitian ini digunakan Teori Kuantifikasi Fuzi yang merupakan metode untuk mengendalikan data-data kualitatif dengan menggunakan himpunan fuzzy. Himpunan ini mempunyai derajat keanggotaan terletak antara rentang 0 sampai 1 . Atribut yang dimiliki dapat secara linguistik dan merupakan penamaan suatu grup yang mewakili kondisi tertentu dengan bahasa alami, misalnya sangat senang, tidak senang, sangat sesuai, sesuai dan sebagainya. Apabila terdapat sampel data $x_{k}(k=1,2, \ldots n)$ dengan derajat keanggotaan $\mu_{B}\left[x_{k}\right]$ pada himpunan fuzzy $B$, dan terdapat sejumlah $S$ himpunan fuzzy, maka dapt dicari mean $\mathrm{m}$ dan mean $\mathrm{m}_{\mathrm{Bi}}(\mathrm{i}=1,2, \ldots \mathrm{S})$ sebagai berikut:

$$
\begin{aligned}
& m=\frac{1}{N}\left\{\sum_{i=k}^{S} \sum_{i=k}^{n} x_{k} \mu_{B i}[x]\right\} \\
& m_{B i}=\frac{1}{N\left(B_{i}\right)}\left\{\sum_{i=k}^{S} x_{k} \mu_{B i}[x]\right\}
\end{aligned}
$$

Total variansi $\mathrm{T}$, variansi antar himpunan fuzi B dan variansi dalam himpunan fuzi E sebagai berikut:

$$
T=\sum_{k=1}^{n} \sum_{i=1}^{S}\left(x_{k}-m\right) \mu_{B i}\left[x_{k}\right]
$$

76 Astuti \& Putri - Teori Kuantifikasi Fuzi II sebagai Alat A nalisis Faktor Kepuasan Konsumen... 


$$
\begin{aligned}
& B=\sum_{k=1}^{n} \sum_{i=1}^{S}\left(m_{B i}-m\right)^{2} \mu_{B i}\left[x_{k}\right] \\
& E=\sum_{k=1}^{n} \sum_{i=1}^{S}\left(x_{k}-m_{B i}\right)^{2} \mu_{B i}\left[x_{k}\right]
\end{aligned}
$$

Dalam hal ini $\mathrm{T}=\mathrm{B}+\mathrm{E}$

Sebagai fungsi tujuan adalah Standar Eksternal $(y)$ dan $y_{k}$ adalah fungsi tujuan dari sampel ke-k, $\mu_{i}(k)$ adalah derajat tanggapan terhadap katagori kualitatif kei $(i=1,2, \ldots$. P) pada sampel ke-k yang berada pada rentang $[0,1]$

Dengan Teori Kuantifikasi Fuzi II maka fungsi tujuan dinyatakan dengan persamaan linier dengan bobot $a_{i}$ untuk katagori $A_{i}$ sebagai :

$y(j)=\sum_{i=1}^{k} a_{i} \mu_{i}[k]$, dengan $j=1,2, \ldots, n$

Nilai bobot $a_{i}$ ditentukan sehingga diperoleh pemisahan yang paling baik untuk setiap standart eksternal himpunan fuzi. Derajat pemisahan ini didefinisikan dengan menggunakan variance ratio $\eta^{2}$ sebagai berikut:

$$
\eta^{2}=\frac{B}{T}
$$

Tabel 1 menunjukkan data-data yang ditangani oleh Teori Kuantifikasi Fuzi II. variabel standart eksternal direpresentasikan sebagai himpunan fuzi $B_{1}, B_{2}, \ldots$, $\mathrm{B}_{\mathrm{M}}$.

Tabel 1. Data-data yang ditangani oleh Teori Kuantifikasi Fuzi II

\begin{tabular}{|c|c|c|}
\hline $\begin{array}{c}N 0 . \\
(\mathrm{j})\end{array}$ & $\begin{array}{c}\text { Kata standard eksternal } \\
\mathrm{B}_{1}, \mathrm{~B}_{2}, \ldots, \mathrm{B}_{\mathrm{M}}\end{array}$ & $\mathrm{A}_{1} \ldots \mathrm{A}_{\mathrm{i}} \ldots \mathrm{A}_{\mathrm{k}}$ \\
\hline 1 & $\mathrm{y}_{1}$ & $\mu_{1}(1) \ldots \mu_{\mathrm{i}}(1) \ldots \mu_{\mathrm{p}}(1)$ \\
2 & $\mathrm{y}_{2}(2) \ldots \mu_{\mathrm{i}}(2) \ldots \mu_{\mathrm{p}}(2)$ \\
3 & $\mathrm{y}_{3}$ & $\mu_{1}(2) \ldots \mu_{\mathrm{i}}(3) \ldots \mu_{\mathrm{p}}(3)$ \\
$\mathrm{j}$ & $\mathrm{y}_{\mathrm{k}}$ & $\mu_{1}(3) \ldots \mu_{\mathrm{i}}$ \\
$\mathrm{n}$ & $\mathrm{y}_{\mathrm{n}}$ & $\mu_{1}(\mathrm{k}) \ldots \mu_{\mathrm{i}}(\mathrm{k}) \ldots \mu_{\mathrm{p}}(\mathrm{k})$ \\
\hline
\end{tabular}

Sebagai parameter adalah atribut dari kelima faktor yang diperoleh dari karakteristik kedua swalayan tersebut.

\section{METODE PENELITIAN}

Subyek penelitian adalah para pelanggan dari kedua swalayan tersebut. Responden yang mengisi kuisioner sebanyak 80 orang.

Untuk menyelesaikan masalah, berikut ini adalah langkah-langkah berdasar Teori Kuantifikasi Fuzi II yang digunakan dalam pengolahan data : 
Langkah 1. Mengumpulkan data karakteristik dari masing-masing swalayan (Indogrosir dan Alfa) yang tentunya berpengaruh terhadap kepuasan konsumen terhadap swalayan tersebut sebagai input pengolahan data.

Langkah 2. Penyebaran kuesioner dilakukan untuk mendapatkan nilai mengenai derajat kepuasan responden terhadap kedua swalayan dan untuk mendapat nilai atau bobot dari faktor-faktor yang berpengaruh.

Langkah 3. Penilaian yang telah diperoleh dikonversikan ke dalam wilayah nilai 0 sampai 1 . Untuk penilaian 1 dikonversikan ke dalam nilai 0; 2 dikonversikan ke dalam nilai 0,25; 3 dikonversikan ke dalam nilai 0,5; 4 dikonversikan ke dalam 0,75 dan 5 dikonversikan ke dalam 1.

Langkah 4. Data-data hasil dari kuisioner di konversi selanjutnya diuji dengan uji kecukupan data, uji validitas, dan reliabilitas data. Bila data tidak cukup maka akan ditambahkan sebesar $\mathrm{n}$ data sesuai dengan jumlah kekurangannya.Apabila data dinyatakan cukup maka data tersebut akan diuji validitasnya.

Langkah 5. Data yang dinyatakan valid segera dilanjutkan dengan uji reliabilitas sedang data yang tidak valid tidak diikut sertakan pada uji reabilitas. Jika keseluruhan data dinyatakan reliable maka data tersebut bisa dilanjutkan pada pengolahan data sel anjutnya.

Langkah 6. Mencari nilai rata-rata bobot kesesuaian faktor yang mempengaruhi kepuasan konsumen dari masing-msing atribut data.

Langkah 7. Melakukan pengolahan dengan metode Teori Kuantifikasi Fuzi II dengan bantuan Sofware MATLAB 6.0 release.

Adapun algoritma Kuantifikasi Fuzi II adalah sebagai berikut :

1) Membentuk matriks $A$, dengan elemen-elemen $\mu_{i}(j), i=1,2, \ldots$, $\mathrm{K}=\mathrm{k}$; dan $\mathrm{j}=1,2, \ldots, \mathrm{n}=\mathrm{jumlah}$ responden; yang diulang sebanyak $M$ jumlah mode kali

2) Membentuk matriks $\bar{A}_{G}$, dengan elemen-elemen $\bar{\mu}_{\mathrm{i}}^{r}, \mathrm{i}=1,2, \ldots$, $\mathrm{K}=\mathrm{k}$; yang diulang sebanyak $\mathrm{n}$ jumlah responden kali untuk suatu nilai $r(r=1, . . M=2)$.

3) Membentuk matriks $\overline{\mathrm{A}}$, dengan elemen-elemen $\bar{\mu}_{\mathrm{i}}, \mathrm{i}=1,2, \ldots$, $\mathrm{k}=\mathrm{k}$; yang diulang sebanyak $\mathrm{Mn}$ kali.

4) Mencari matriks $S_{G}$ dan $S$ yang berukuran $K x K$

5) Mendekomposisikan $S$ menjadi matriks segitiga $\Delta$

6) Kemudian dapat dicari matriks $\gamma$

7) Untuk memaksimumkan fuzzy variance ratio $\eta^{2}$, dapat dicari melalui eigenvector $\Delta$ a, yang memaksimumkan eigenvalue $\eta^{2}$

8) Menentukan persamaan $y(j), j=1,2, \ldots, 70$

Dalam penelitian ini uji kecukupan digunakan untuk menentukan apakah sample yang diambil mampu mewakili populasi yang ada. Sedangkan uji validitas dan reliabilitas digunakan untuk mengetahui apakah data valid dan reliable untuk diolah lebih lanjut..Persamaan regresi yang dibangun antara pemilihan swalayan Indogrosir dan Alfa (variabel standar ekstrenal) dan penilaian faktor-faktor yang mempengaruhinya (variabel parameter) dengan Kuantifikasi Fuzi II dapat digunakan untuk menentukan swalayan mana yang

78 Astuti \& Putri - Teori Kuantifikasi Fuzi II sebagai Alat A nalisis Faktor Kepuasan Konsumen... 
paling sesuai dengan konsumen, serta mengetahui swalayan mana yang memiliki bobot kepuasan konsumen tertinggi.

\section{HASIL PENELITIAN}

Data observasi yang dilakukan terhadap 80 responden dilakukan perhitungan uji kecukupan data. Ukuran kecukupan sampel yang dibutuhkan dengan menggunakan tingkat kepercayaan $95 \%$ (nilai $Z_{a / 2}=1.96$ ), tingkat ketelitian sampel $5 \%$, nilai $z$ yang berhubungan dengan tingkat ketelitian $Z_{\mathrm{a} / 2}=1.29$ dan proporsi yang diduga $80 / 90=0.89$ yaitu:

$$
N^{\prime}=0.89(1-0.89)\left[\frac{1.29}{5 \%}\right]^{2}=65.17
$$

\section{PEMBAHASAN}

\subsection{A nalisa Uji Kecukupan, V aliditas dan Reliabilitas D ata}

Jumlah sampel $(\mathrm{N})$ sebanyak 80 orang dinyatakan cukup mewakili populasi karena sesuai dengan perhitungan rumus jumlah minimal yang harus diambil N' ( 65.17) lebih kecil dari N.

Pada uji validitas (Tabe 2) kedua swalayan dinyatakan valid karena keduanya mempunyai nilai korelasi bagian total $r$ hitung lebih besar dari nilai $r$ tabel (0.156) Berdasarkan uji validasi dari 22 butir sub faktor yang dinyatakan valid berjumlah 18, yaitu keragaman barang, kelengkapan merek produk, kualitas/ mutu barang, ketersediaaan/ stok barang, jaminan/ garansi, harga barang relatif murah, program potongan dan penurunan harga, kredit barang elektronik, kredit untuk pedagang, pemilihan lokasi, layout dan kondisi ruangan, sarana parkir, fasilitas pendukung, kartu anggota, hadiah-hadiah, voucher belanja, kinerja karyawan, serta kelengkapan fasilitas pelayanan belanja. Hal itu berarti kedelapan belas faktor-faktor itulah yang layak untuk diproses pada pengolahan selanjutnya.

Pada uji reabilitas dari 20 data (swalayan dan faktor-faktor) yang dinyatakan valid, didapat $r$ alpha sebesar 0.731 yang berarti lebih besar dari $r$ tabel. Hal ini berarti 20 data tersebut dinyatakan reliable atau bisa dipercaya untuk melakukan penelitian yang diinginkan. 
Tabel 2. Hasil uji validitas

\begin{tabular}{|c|c|c|c|}
\hline No & Butir & $\begin{array}{c}\text { Corrected item total } \\
\text { correlation }\end{array}$ & Keterangan \\
\hline 1 & Indogrosir & $0.603\left({ }^{* *}\right)$ & Valid \\
\hline 2 & Alfa & $0.464(* *)$ & Valid \\
\hline 3 & Keragaman barang & $0.401\left(^{* *}\right)$ & Valid \\
\hline 4 & Kelengkapan berbagai merek produk & $0.480(* *)$ & Valid \\
\hline 5 & Kualitas/ mutu barang & 0.586 (**) & Valid \\
\hline 6 & Ketersediaan/ stok barang & $0.451(* *)$ & Valid \\
\hline 7 & Jaminan/ garansi & $0.462(* *)$ & Valid \\
\hline 8 & Harga barang relatif murah & $0.363(* *)$ & Valid \\
\hline 9 & Program potongan \& penurunan harga & $0.672(* *)$ & Valid \\
\hline 10 & Fasilitas kredit barang elektronik & $0.671(* *)$ & Valid \\
\hline 11 & Fasilitas kredit untuk pedagang eceran & $0.501(* *)$ & Valid \\
\hline 12 & Pemilihan Iokasi & 0.586 (**) $^{* *}$ & Valid \\
\hline 13 & Layout\&kondisi ruangan & $0.496(* *)$ & Valid \\
\hline 14 & Ketersediaan sarana parkir & $0.495(* *)$ & Valid \\
\hline 15 & Ketersediaan fasilitas pendukung & $0.454(* *)$ & Valid \\
\hline 16 & Kartu anggota & $0.288(* *)$ & Valid \\
\hline 17 & Hadiah-hadiah & $0.447(* *)$ & Valid \\
\hline 18 & Voucher belanja & $0.622(* *)$ & Valid \\
\hline 19 & Kinerja karyawan & $0.317(* *)$ & Valid \\
\hline 20 & Kelengkapan fasilitas pelayanan belanja & $0.314(* *)$ & Valid \\
\hline
\end{tabular}

\subsection{A nalisa Rata-rata Bobot Kesesuaian Faktor}

Dari pertimbangan 80 responden, ternyata peringkat bobot kesesuaian kepuasan adal ah sebagai ditunjukkan pada Tabel 3.

Tabel 3. Rata-rata bobot kesesuaian faktor

\begin{tabular}{|l|c|}
\hline Faktor-faktor & Rata-rata bobot \\
\hline Keragaman barang & 0.95 \\
\hline Kelengkapan berbagai merek produk & 0.83 \\
\hline Kualitas/ mutu barang & 0.89 \\
\hline Ketersediaan/ stok barang & 0.83 \\
\hline Jaminan/ garansi & 0.50 \\
\hline Harga barang relatif murah dan terjangkau & 0.94 \\
\hline Program potongan \& penurunan harga & 0.91 \\
\hline Fasilitas kredit barang elektronik & 0.76 \\
\hline Fasilitas kredit untuk pedagang eceran & 0.52 \\
\hline Pemilihan lokasi & 0.93 \\
\hline Layout\&kondisi ruangan & 0.89 \\
\hline Ketersediaan sarana parkir & 0.92 \\
\hline Ketersediaan fasilitas pendukung & 0.84 \\
\hline Kartu anggota & 0.94 \\
\hline Hadiah-hadiah & 0.90 \\
\hline Voucher belanja & 0.81 \\
\hline Kinerja karyawan & 0.90 \\
\hline Kelengkapan fasilitas pelayanan belanja & 0.89 \\
\hline
\end{tabular}

Dari Tabel 3 dapat disusun peringkat sebagi berikut:

a. Peringkat pertama, ditempati oleh faktor keragaman barang yang disediakan , dengan bobot 0.95 .

b. Peringkat ke-dua, ditempati 2 faktor, yaitu harga barang yang relatif murah dan terjangkau, serta promosi melalui kartu anggota yang memiliki banyak manfaat, kedua faktor tersebut memiliki bobot yang sama, yaitu 0.94 .

80 Astuti \& Putri - Teori Kuantifikasi Fuzi II sebagai Alat A nalisis Faktor Kepuasan Konsumen... 
c. Peringkat ketiga, ditempati faktor pemilihan lokasi. Lokasi di pinggir kota yang tidak terlalu ramai namun bersih, aman, nyaman, dan mengutamakan kemudahan jalur dan sarana transportasi memiliki bobot 0.93 .

d. Peringkat ke-empat, ditempati faktor ketersediaan parkir. Pakir yang luas, penataan teratur, bersih, nyaman dan tidak dipungut biaya memiliki bobot 0.92 .

e. Peringkat ke-lima, ditempati faktor program potongan dan penurunan harga yang diadakan, dengan bobot 0.91 .

f. Peringkat ke-enam, ditempati 2 faktor, yaitu hadih-hadiah dan kinerja karyawan dalam melayani konsumen, dengan bobot 0.90

g. Peringkat ketujuh, ditempati 3 faktor, yaitu kualitas/mutu barang, layout dan kondisi ruangan, dan kelengkapan fasilitas pelayanan belanja, dengan bobot 0.89 .

h. Peringkat kedelapan, ditempati faktor ketersediaan fasilitas pendukung, seperti ATM, kantin, telephone umum, dan sebagainya, dengan bobot 0.84 .

i. Peringkat ke-sembilan, ditempati 2 faktor, yaitu kelengkapan merek produk dan ketersedian/ stok barang, dengan bobot 0.83 .

j. Peringkat kesepuluh, ditempati faktor voucher belanja produk sponsor, dengan bobot 0.82 .

k. Peringkat ke-sebelas, ditempati faktor fasilitas kredit barang elektronik, dengan bobot 0.76

I. Peringkat keduabelas, ditempati faktor fasilitas kredit untuk pedagang, dengan bobot 0.52 .

m. Peringkat ketigabelas, ditempati faktor jaminan/ garansi barang yang rusak untuk kasus tertentu, dengan bobot 0.50 .

\subsection{Persamaan Regresi $\mathbf{y}(\mathbf{j})$ dan Regresi Liner (z(i))}

Berdasarkan hasil pengolahan hubungan antara derajat kepuasan konsumen terhadap Indogrosir dan Alfa ( variabel standart eksternal ) dengan faktor-faktor yang mempengaruhinya (parameter), menggunakan software Matlab versi 6 release 12, diperoleh persamaan y(j) untuk mengetahui hubungan faktor- faktor yang mempengaruhi kepuasan konsumen dengan pemilihan terhadap swalayan tersebut (Tabel 4).

Tabel 4. Persamaan regresi derajat kepuasan dan faktor yang berpengaruh

\begin{tabular}{|c|c|c|}
\hline No & Keterangan & Persamaan \\
\hline 1 & $\begin{array}{l}\text { Persamaan regresi bobot } \\
\text { kesesuaian faktor-faktor }\end{array}$ & $\begin{aligned} y(j)= & 0.1946 \mu_{1}(j)-0.0224 \mu_{2}(j)-0.0790 \mu_{3}(j)+ \\
& 0.0123 \mu_{4}(j)-0.1559 \mu_{5}(j)-0.2047 \mu_{6}(j)- \\
& 0.0307 \mu_{7}(j)-0.0683 \mu_{8}(j)+0.0617 \mu_{9}(j)+ \\
& 0.3635 \mu_{10}(j)-0.1936 \mu_{11}(j)-0.0013 \mu_{12}(j)+ \\
& 0.0393 \mu_{13}(j)+0.3069 \mu_{14}(j)+0.1298 \mu_{15}(j)+ \\
& 0.2091 \mu_{16}(j)+0.2306 \mu_{17}(j)-0.0144 \mu_{18}(j)\end{aligned}$ \\
\hline 2 & Regresi linear Indogrosir & $z_{1}=-1.6315 * y(j)+1.9358$ \\
\hline 3 & Regresi linear Alfa & $z_{2}=1.5248 * y(j)-0.5176$ \\
\hline
\end{tabular}

Dari hasil persamaan $y(j)$, hubungan antara parameter dengan standard eksternal diperoleh nilai bahwa keragaman barang, ketersediaan/ stok barang, kredit untuk pedagang, pemilihan lokasi, fasilitas pendukung, promosi melalui kartu anggota, hadiah-hadiah, voucher belanja, dan kinerja karyawan akan memberikan kontribusi yang positif pada nilai y total. 
Nilai y total ini akan sangat berpengaruh pada hasil persamaan tiap swalayan, dimana hal itu yang akan menentukan swalayan mana yang mempunyai nilai $z$ tertinggi atau dalam kata lain yang paling memuaskan konsumennya.

Selain persamaan $y(j)$, juga diperoleh persamaan regresi linier (zi) untuk masing-masing swalayan yang diteliti (Tabel 4). Regresi itu berfungsi untuk mengetahui swalayan mana yang memberikan kepuasan tertinggi bagi masingmasing responden serta faktor apa yang mempengaruhinya.

Data pertimbangan responden ke-1 pada pengisian kuisioner yang sudah dilakukan, di subtitusikan ke dalam persamaan y(j), didapat $y(1)$ sebear 0.64 . Kemudian $y(1)$ disubtitusikan kedalam persamaan regresi linier $(z(i))$, setelah itu diperoleh $z$ (Indogrosir) sebesar 0.89, sedangkan untuk z(Alfa) sebesar 0.46, nilai error terbesar (dengan minus terbesar) berada di kolom Alfa. Maka kesimpulannya responden ke-1 lebih sesuai berbelanja di Indogrosir karena sesuai dengan pertimbangan bagi dirinya sendiri. Untuk responden 2 dan seterusnya dapat dilihat pada Tabel 5 .

Tabel 5. Hubungan y(j) dengan standard eksternal real, hasil regresi dan error

\begin{tabular}{|c|c|c|c|c|c|c|c|}
\hline \multirow{2}{*}{$\begin{array}{l}\text { Respon- } \\
\text { den }\end{array}$} & \multirow[t]{2}{*}{$y(j)$} & \multicolumn{2}{|c|}{$\begin{array}{c}\text { External } \\
\text { standard real }\end{array}$} & \multicolumn{2}{|c|}{$\begin{array}{c}\text { External } \\
\text { standard regresi }\end{array}$} & \multicolumn{2}{|c|}{ Error } \\
\hline & & Indogrosir & Alfa & Indogrosir & Alfa & Indogrosir & Alfa \\
\hline 1 & 0.64 & 0.75 & 0.5 & 0.89 & 0.46 & 0.14 & -0.04 \\
\hline 2 & 0.66 & 0.75 & 0.5 & 0.86 & 0.49 & 0.11 & -0.01 \\
\hline 3 & 0.67 & 0.75 & 0.75 & 0.84 & 0.51 & 0.09 & -0.24 \\
\hline 4 & 0.66 & 0.75 & 0.75 & 0.87 & 0.48 & 0.12 & -0.27 \\
\hline 5 & 0.69 & 0.75 & 0.75 & 0.81 & 0.53 & 0.06 & -0.22 \\
\hline 6 & 0.82 & 0.75 & 0.75 & 0.59 & 0.74 & -0.16 & -0.01 \\
\hline 7 & 0.70 & 1 & 0.75 & 0.80 & 0.54 & -0.20 & -0.21 \\
\hline 8 & 0.79 & 1 & 0.75 & 0.64 & 0.69 & -0.36 & -0.06 \\
\hline 9 & 0.70 & 1 & 0.5 & 0.79 & 0.55 & -0.21 & 0.05 \\
\hline 10 & 0.72 & 1 & 0.5 & 0.77 & 0.58 & -0.23 & 0.08 \\
\hline 11 & 0.72 & 1 & 0.5 & 0.76 & 0.59 & -0.24 & 0.09 \\
\hline 12 & 0.82 & 1 & 0.5 & 0.59 & 0.74 & -0.41 & 0.24 \\
\hline 13 & 0.57 & 1 & 0.5 & 1.00 & 0.35 & 0.00 & -0.15 \\
\hline 14 & 0.74 & 1 & 0.5 & 0.74 & 0.60 & -0.26 & 0.10 \\
\hline 15 & 0.61 & 0.5 & 0.5 & 0.94 & 0.41 & 0.44 & -0.09 \\
\hline 16 & 0.66 & 0.75 & 0.5 & 0.86 & 0.49 & 0.11 & -0.01 \\
\hline 17 & 0.73 & 0.75 & 0.5 & 0.74 & 0.60 & -0.01 & 0.10 \\
\hline 18 & 0.69 & 0.75 & 0.5 & 0.81 & 0.54 & 0.06 & 0.04 \\
\hline 19 & 0.69 & 0.75 & 0.5 & 0.81 & 0.54 & 0.06 & 0.04 \\
\hline 20 & 0.66 & 0.75 & 0.25 & 0.86 & 0.49 & 0.11 & 0.24 \\
\hline 21 & 0.69 & 0.75 & 0.5 & 0.81 & 0.54 & 0.06 & 0.04 \\
\hline 22 & 0.62 & 0.75 & 0.5 & 0.93 & 0.42 & 0.18 & -0.08 \\
\hline 23 & 0.69 & 0.75 & 0.5 & 0.81 & 0.54 & 0.06 & 0.04 \\
\hline 24 & 0.74 & 1 & 0.5 & 0.73 & 0.61 & -0.27 & 0.11 \\
\hline
\end{tabular}

Tabel 5. Lanjutan.

\begin{tabular}{|c|c|c|c|c|c|c|c|}
\hline \multirow{2}{*}{$\begin{array}{c}\text { Respon- } \\
\text { den }\end{array}$} & \multirow{2}{*}{$\mathrm{y}(\mathrm{j})$} & \multicolumn{2}{|c|}{$\begin{array}{c}\text { External } \\
\text { standard real }\end{array}$} & \multicolumn{2}{c|}{$\begin{array}{c}\text { External } \\
\text { standard regresi }\end{array}$} & \multicolumn{3}{c|}{ Error } \\
\cline { 3 - 8 } & & Indogrosir & Alfa & Indogrosir & Alfa & Indogrosir & Alfa \\
\hline 25 & 0.74 & 0.75 & 0.5 & 0.73 & 0.61 & -0.02 & 0.11 \\
\hline 26 & 0.67 & 1 & 0.5 & 0.84 & 0.50 & -0.16 & 0.00 \\
\hline 27 & 0.57 & 1 & 0.5 & 1.00 & 0.35 & 0.00 & -0.15 \\
\hline 28 & 0.61 & 1 & 0.75 & 0.94 & 0.42 & -0.06 & -0.33 \\
\hline 29 & 0.70 & 0.75 & 0.75 & 0.79 & 0.56 & 0.04 & -0.19 \\
\hline
\end{tabular}

82 Astuti \& Putri - Teori Kuantifikasi Fuzi II sebagai Alat A nalisis Faktor Kepuasan Konsumen... 


\begin{tabular}{|c|c|c|c|c|c|c|c|}
\hline 30 & 0.70 & 1 & 0.75 & 0.79 & 0.55 & -0.21 & -0.20 \\
\hline 31 & 0.72 & 1 & 0.25 & 0.76 & 0.58 & -0.24 & 0.33 \\
\hline 32 & 0.79 & 1 & 0.25 & 0.65 & 0.68 & -0.35 & 0.43 \\
\hline 33 & 0.80 & 1 & 0.5 & 0.63 & 0.70 & -0.37 & 0.20 \\
\hline 34 & 0.82 & 1 & 0.5 & 0.59 & 0.74 & -0.41 & 0.24 \\
\hline 35 & 0.75 & 1 & 0.5 & 0.71 & 0.63 & -0.29 & 0.13 \\
\hline 36 & 0.77 & 1 & 0.5 & 0.68 & 0.66 & -0.32 & 0.16 \\
\hline 37 & 0.73 & 1 & 0.5 & 0.74 & 0.60 & -0.26 & 0.10 \\
\hline 38 & 0.79 & 1 & 0.5 & 0.65 & 0.69 & -0.35 & 0.19 \\
\hline 39 & 0.77 & 1 & 0.25 & 0.68 & 0.65 & -0.32 & 0.40 \\
\hline 40 & 0.80 & 1 & 0.25 & 0.63 & 0.70 & -0.37 & 0.45 \\
\hline 41 & 0.71 & 1 & 0.25 & 0.78 & 0.56 & -0.22 & 0.31 \\
\hline 42 & 0.88 & 1 & 0.5 & 0.50 & 0.83 & -0.50 & 0.33 \\
\hline 43 & 0.87 & 1 & 0.5 & 0.51 & 0.82 & -0.49 & 0.32 \\
\hline 44 & 0.87 & 1 & 0.5 & 0.52 & 0.81 & -0.48 & 0.31 \\
\hline 45 & 0.82 & 1 & 0.25 & 0.59 & 0.74 & -0.41 & 0.49 \\
\hline 46 & 0.88 & 1 & 0.25 & 0.50 & 0.82 & -0.50 & 0.57 \\
\hline 47 & 0.87 & 1 & 0.25 & 0.52 & 0.81 & -0.48 & 0.56 \\
\hline 48 & 0.88 & 1 & 0.25 & 0.50 & 0.82 & -0.50 & 0.57 \\
\hline 49 & 0.75 & 1 & 0.5 & 0.71 & 0.63 & -0.29 & 0.13 \\
\hline 50 & 0.81 & 1 & 0.5 & 0.62 & 0.72 & -0.38 & 0.22 \\
\hline 51 & 0.82 & 1 & 0.5 & 0.60 & 0.73 & -0.40 & 0.23 \\
\hline 52 & 0.76 & 1 & 0.75 & 0.69 & 0.65 & -0.31 & -0.10 \\
\hline 53 & 0.81 & 1 & 0.75 & 0.62 & 0.71 & -0.38 & -0.04 \\
\hline 54 & 0.84 & 1 & 0.5 & 0.57 & 0.76 & -0.43 & 0.26 \\
\hline 55 & 0.87 & 1 & 0.25 & 0.51 & 0.81 & -0.49 & 0.56 \\
\hline 56 & 0.86 & 1 & 0.75 & 0.54 & 0.79 & -0.46 & 0.04 \\
\hline 57 & 0.88 & 1 & 0.25 & 0.50 & 0.82 & -0.50 & 0.57 \\
\hline 58 & 0.90 & 1 & 0.25 & 0.47 & 0.86 & -0.53 & 0.61 \\
\hline 59 & 0.86 & 1 & 0.25 & 0.53 & 0.80 & -0.47 & 0.55 \\
\hline 60 & 0.79 & 1 & 0.5 & 0.65 & 0.69 & -0.35 & 0.19 \\
\hline 61 & 0.85 & 1 & 0.5 & 0.55 & 0.78 & -0.45 & 0.28 \\
\hline 62 & 0.91 & 0.75 & 0.5 & 0.45 & 0.87 & -0.30 & 0.37 \\
\hline 63 & 1.01 & 0.75 & 0.5 & 0.29 & 1.00 & -0.46 & 0.50 \\
\hline 64 & 1.01 & 0.75 & 0.5 & 0.29 & 1.00 & -0.46 & 0.50 \\
\hline 65 & 0.83 & 1 & 0.5 & 0.58 & 0.75 & -0.42 & 0.25 \\
\hline 66 & 0.84 & 0.75 & 0.5 & 0.57 & 0.76 & -0.18 & 0.26 \\
\hline 67 & 0.81 & 1 & 0.5 & 0.62 & 0.71 & -0.38 & 0.21 \\
\hline 68 & 0.87 & 0.75 & 0.75 & 0.52 & 0.80 & -0.23 & 0.05 \\
\hline 69 & 0.97 & 0.5 & 0.75 & 0.36 & 0.96 & -0.14 & 0.21 \\
\hline 70 & 0.96 & 1 & 0.75 & 0.37 & 0.95 & -0.63 & 0.20 \\
\hline 71 & 0.86 & 1 & 0.5 & 0.54 & 0.79 & -0.46 & 0.29 \\
\hline 72 & 0.87 & 1 & 0.5 & 0.52 & 0.81 & -0.48 & 0.31 \\
\hline 73 & 0.87 & 1 & 0.5 & 0.52 & 0.80 & -0.48 & 0.30 \\
\hline 74 & 0.85 & 1 & 0.5 & 0.55 & 0.78 & -0.45 & 0.28 \\
\hline
\end{tabular}

Tabel 5. Lanjutan.

\begin{tabular}{|c|c|c|c|c|c|c|c|}
\hline \multirow{2}{*}{$\begin{array}{c}\text { Respon- } \\
\text { den }\end{array}$} & \multirow{2}{*}{$\mathrm{y}(\mathrm{j})$} & \multicolumn{2}{|c|}{$\begin{array}{c}\text { External } \\
\text { standard real }\end{array}$} & \multicolumn{2}{c|}{$\begin{array}{c}\text { External } \\
\text { standard regresi }\end{array}$} & \multicolumn{3}{c|}{ Error } \\
\cline { 3 - 9 } & & Indogrosir & Alfa & Indogrosir & Alfa & Indogrosir & Alfa \\
\hline 75 & 0.81 & 1 & 0.5 & 0.62 & 0.72 & -0.38 & 0.22 \\
\hline 76 & 0.89 & 1 & 0.5 & 0.48 & 0.84 & -0.52 & 0.34 \\
\hline 77 & 0.94 & 1 & 0.75 & 0.40 & 0.92 & -0.60 & 0.17 \\
\hline 78 & 0.86 & 1 & 0.75 & 0.54 & 0.79 & -0.46 & 0.04 \\
\hline 79 & 0.90 & 1 & 0.75 & 0.47 & 0.85 & -0.53 & 0.10 \\
\hline 80 & 0.84 & 1 & 0.25 & 0.57 & 0.76 & -0.43 & 0.51 \\
\hline
\end{tabular}

Tabel 6. Nilai Z berdasarkan nilai rata-rata $(\bar{y})$ 


\begin{tabular}{|l|c|}
\hline Swalayan & Bobot Z \\
\hline Indogrosir & 0.65 \\
\hline Alfa & 0.69 \\
\hline
\end{tabular}

\subsection{Perbandingan Bobot Kepuasan Konsumen Terhadap M asing-masing}

Swalayan

Berdasarkan nilai rata-rata $\mathrm{y}(\mathrm{j})=0,79$ untuk 80 responden, dari persamaan regresi linier untuk masing-masing swalayan (Tabel 6) diperoleh $Z$ (Indogrosir) sebesar 0.65 , sedangkan Z(Alfa) sebesar 0.69 .

\section{SIMPULAN}

Dari hasil penelitian dapat diperoleh simpulan sebagai berikut:

1. Berdasarkan peringkat rata-rata bobot kesesuaian faktor-faktor dari 80 responden yang telah mengisi kuisioner dan merupakan konsumen dari Swalayan berbasis grosir dan retail yakni Indogrosir dan Alfa, dapat diketahui bahwa peringkat teratas adalah faktor keragaman barang. Ini menunjukkan bahwa di antara faktor-faktor yang ada lainnya, ternyata keragaman barang merupakan faktor yang paling dominan. Faktor terendah adalah jaminan atau garansi barang yang rusak. Berarti konsumen menempatkan soal jaminan pada bagian terakhir

2. Berdasarkan Teori Kuantifikasi Fuzi II, rata-rata persamaan regresi y(j), yang kemudian disubtitusikan ke dalam regresi linier Zi masing-masing swalayan, diketahui bahwa bobot kepuasan konsumen terhadap Alfa sebesar 0.69, dan terhadap Indogrosir sebesar 0.65.

\section{PUSTAKA}

[1] Sutrisno, H. (1991) A nalisis Butir U ntuk Instrumen, Andi Offset, Yogyakarta.

[2] Kusumadewi, S. (2002) A nalisis dan D esain Sistem Fuzzy M enggunakan Tool Box M atlab, Graha IImu, Yogyakarta.

[3] Kusumadewi, S. (2003) Artificial Intelligence: Teknik dan A plikasiny, Graha IImu, Yogyakarta.

[4] Kusumadewi, S., dan Purnomo, H. (2004) A plikasi Logika Fuzzy untuk Pendukung Keputusan, Graha IImu, Yogyakarta.

[5] Teguh (2004) Cara Mudah M elakukan Analisa Statistik dengan SPSS, Gava Media, Yogyakarta.

84 Astuti \& Putri - Teori Kuantifikasi Fuzi II sebagai Alat A nalisis Faktor Kepuasan Konsumen... 